\title{
Impact of climate change on the distribution of a giant land snail from South America: predicting future trends for setting conservation priorities on native malacofauna
}

\author{
Ariel A. Beltramino ${ }^{1,2} \cdot$ Roberto E. Vogler ${ }^{2,3}$. \\ Diego E. Gutiérrez Gregoric ${ }^{1,2}$ - Alejandra Rumi ${ }^{1,2}$
}

Received: 19 December 2014 / Accepted: 2 April 2015 / Published online: 18 April 2015

(C) Springer Science+Business Media Dordrecht 2015

\begin{abstract}
Many land snails are vulnerable to climate change as a consequence of small distribution ranges and poor dispersal. South America is a diverse region in terms of land snail fauna, but studies about the impacts of climate change on molluscan biodiversity are virtually nonexistent. Bioclimatic models provide an important tool to assess how habitat suitability may change in a warming planet. In this study, we examine potential impacts of climate change on a giant land snail (Megalobulimus sanctipauli) from the Atlantic Forest to predict future shifts in its potential distribution, and to identify protected areas that may contain suitable habitat for setting conservation priorities. Using a maximum entropy algorithm, we modeled the species' potential distribution across South America under current climatic conditions and projected the results onto two climate change scenarios for two time frames. A $2.17 \%$ of South America on the Atlantic Forest was predicted to be currently suitable for the species, comprising the border area among Argentina, Brazil and Paraguay. Prognosis of future distribution showed a trend to a northern retraction, but a southern expansion of current potential range. More than 150 protected areas were identified to contain climatically suitable habitat for the species, but on the less optimistic outlook only $\sim 1545 \mathrm{~km}^{2}$ of protected areas $(0.009 \%$ of South America) would remain suitable for the species by the end of the century. Our findings are expected to improve understanding of climate change impacts on native giant land snails and to contribute in conservation efforts on this malacofauna.
\end{abstract}

Electronic supplementary material The online version of this article (doi:10.1007/s10584-015-1405-3) contains supplementary material, which is available to authorized users.

Ariel A. Beltramino

aabeltramino@fcnym.unlp.edu.ar; beltraminoariel@hotmail.com

1 División Zoología Invertebrados, Facultad de Ciencias Naturales y Museo, Universidad Nacional de La Plata, Paseo del Bosque s/n, B1900FWA La Plata, Argentina

2 Consejo Nacional de Investigaciones Científicas y Técnicas (CONICET), Buenos Aires, Argentina

3 Departamento de Biología, Facultad de Ciencias Exactas, Químicas y Naturales, Universidad

Nacional de Misiones, Rivadavia 2370, N3300LDX Posadas, Argentina 


\section{Introduction}

Climate change is recognized as one of the major drivers of biodiversity changes across the globe. Some of the documented effects of climate change on biodiversity during the 20th century include alterations in the distribution, phenology, and increase in extinction risk of many species (Vale et al. 2009 and references therein). A rapid and greater climate change has been predicted for the 21st century, which is expected to affect all the levels of biodiversity, from organisms to biomes (Cordellier et al. 2012; Bellard et al. 2012). Moreover, a growing body of data indicates that climate change will be one of the major drivers of species extinction in this century (Thomas et al. 2004; Foden et al. 2008).

Five trait groups associated with extinction risk due to climate change form the basis of IUCN's criteria to assess species susceptibility to climate change (Foden et al. 2008): a- habitat specialization, b- narrow environmental tolerances, c- dependence on specific environmental triggers, $\mathrm{d}$ - dependence on interspecific interactions, and e- poor ability to disperse to or colonize a new range. The latter trait group has been pointed out as particularly important for those species with low dispersal rates that are unlikely to migrate fast enough to more suitable environmental conditions, such as land snails (Foden et al. 2008; Kramarenko 2014). Thus, because of small distribution ranges and poor dispersal, many land snails will face elevated extinction risk as their habitats become exposed to substantial climatic changes (Foden et al. 2008; Sen et al. 2012).

South America is a diverse region in terms of land snail fauna, harboring high species diversity and endemism (Fernández 1973; Quintana 1982; Salgado and Coelho 2003; Ramírez et al. 2003; Simone 2006; Breure and Romero 2012; Gutiérrez Gregoric et al. 2013). Among the most distinctive elements of malacofauna of South America are the species of the endemic genus Megalobulimus Miller, 1878. This genus includes the largest land snails of the continent, many of which are tied to the rich cultural heritage of South America (Eggers et al. 2011; Jaramillo Roldán et al. 2014). Megalobulimus are mostly nocturnal snails that have been littlestudied in the wild, including few data on their distributional ranges. Most of the species within the group occur in relatively small populations, with individuals mostly hidden in the soil or under leaf litter (Hylton Scott 1939; Bequaert 1948; Miranda et al. 2015). These giant snails are of great conservation concern because many species are endangered (Santos et al. 2013). The synergistic effect of life history traits such as long lifespan, low reproductive potential, late reproductive maturity, and limited vagility (Miranda et al. 2015 and references therein) reduce the capacity for population recovery, and any disturbance in habitat requirements and/or life cycle represents a potential threat. At present, several of these snails are listed as threatened due to habitat loss by anthropogenic activities (Agudo-Padrón 2011; Santos et al. 2013; IUCN 2014; Miranda et al. 2015). In addition, in order to focus attention on the conservation of the poorly known land snails of the Atlantic Forest, especially the almost completely unknown microsnails, some species of Megalobulimus have been recently proposed as umbrella and flagship species (Santos 2011).

In recent years, the knowledge about the possible impacts of climate change over South America has markedly increased (Vale et al. 2009). However, studies about the effects on molluscan biodiversity are virtually nonexistent and impacts on giant land snail fauna remain unexplored. In this context, species distribution models (SDMs, also known as bioclimatic models and ecological niche models) constitute important tools to predict future changes in the species geographic ranges, and are currently the most widely used approaches to examine potential impacts of climate change on biodiversity (Jeschke and Strayer 2008; Franklin et al. 2013; Vogler et al. 2013). 
Here, we investigate potential impacts of climate change on a giant land snail by modeling the potential distribution of Megalobulimus sanctipauli (Ihering and Pilsbry, 1900) across its known distributional range in South America, under current and future climatic conditions. M. sanctipauli is known to inhabit the Atlantic Forest, and living specimens were recently confirmed to occur in the southernmost areas of this forest (Fig. 1; Beltramino et al. 2012; Beltramino 2013; Gutiérrez Gregoric et al. 2013). This species is being severely impacted by human activity due to habitat loss and environmental degradation (Di Bitetti et al. 2003; Bonard et al. 2012). An additional threat to this snail today is from control programs being developed in Argentina, Brazil and Paraguay against invasive species, specifically the giant African snail Achatina fulica Bowdich, 1822 (Fischer and Costa 2010; Gutiérrez Gregoric et al. 2013), as local populations of M. sanctipauli are being reduced because their individuals are often confused with those of the invasive snail.

Our main goals were to determine: a- the potential distribution of M. sanctipauli in South America under current climatic conditions; $b$ - the areas that are likely to be most affected by climate change in different time slices and under different climate change scenarios; and c-

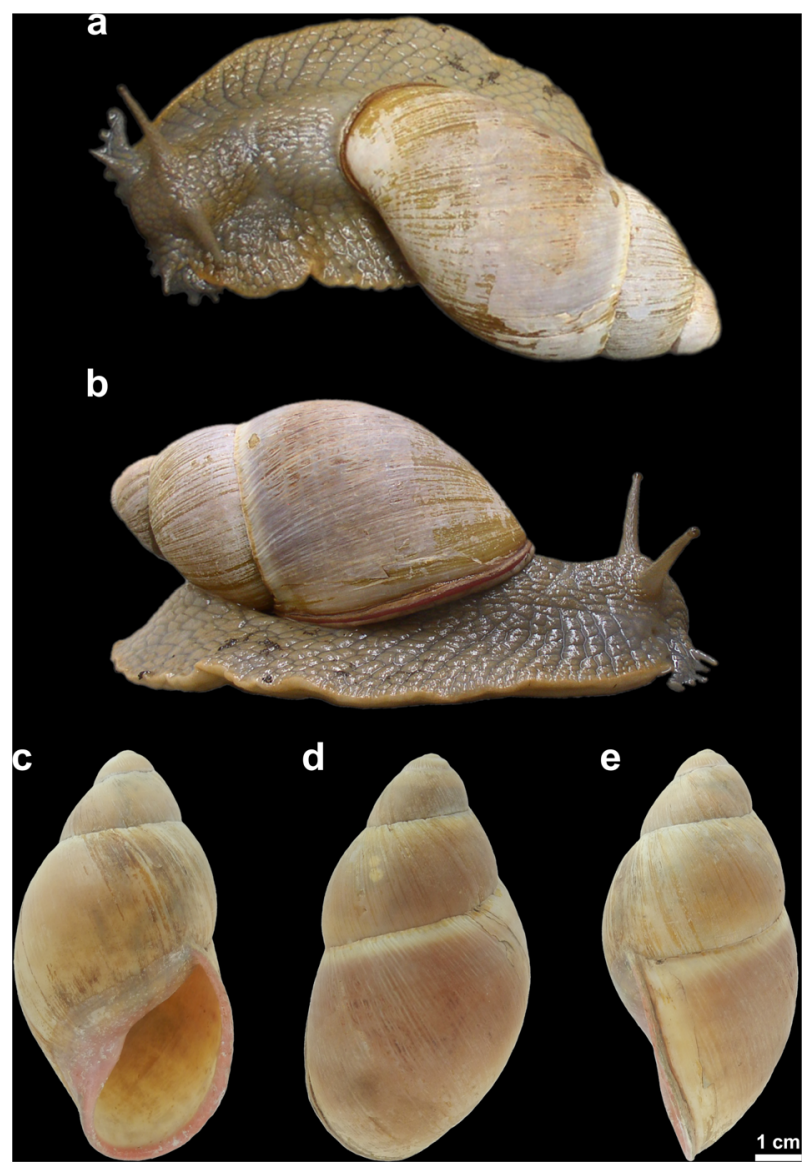

Fig. 1 Adult specimen of Megalobulimus sanctipauli from Puerto Iguazú city, northeastern Argentina $\left(25^{\circ} 35^{\prime}\right.$ $\left.47^{\prime \prime} \mathrm{S}, 54^{\circ} 35^{\prime} 26^{\prime \prime} \mathrm{W}\right)$. a, b living specimen: a dorsal, and b lateral view. c-e shell views: c frontal, $\mathbf{d}$ dorsal, and e lateral view 
protected areas that contain climatically suitable habitat at present and future for setting conservation priorities and research in this species. Our findings are expected to improve understanding of the effect of climate change on native giant land snails.

\section{Materials and methods}

\subsection{Study area and species records}

Historical distribution of Megalobulimus sanctipauli involves Argentina, Brazil and Paraguay (Beltramino 2013). As the potential distribution of the species may not necessarily be limited to the mentioned countries, we chose to evaluate its distributional range across all South American countries $\left(17,825,184 \mathrm{~km}^{2}\right)$ : Argentina, Bolivia, Brazil, Chile, Colombia, Ecuador, French Guiana, Guyana, Paraguay, Peru, Suriname, Uruguay and Venezuela. M. sanctipauli comprises three nominal subspecies: M. sanctipauli sanctipauli (Ihering and Pilsbry, 1900), M. sanctipauli pygmaeus (Bequaert, 1948) and M. sanctipauli eyerdami (Bequaert, 1948). This study was based on presence data $(n=20)$ for $M$. s. sanctipauli that were obtained from the scientific literature (Fernández 1978; Beltramino et al. 2012; Beltramino 2013 and references therein). For those localities where the coordinates were not provided by the source, a georeferenced position was derived secondarily by using the point-radius method described in Wieczorek et al. (2004). In relation to the other subspecies, only a single presence record is currently available for each of them from the original descriptions (Bequaert 1948; Beltramino et al. 2012). Given the magnitude of uncertainty due to the extent of the locality, these records could not be used here as presence data (i.e., the type locality for M. s. pygmaeus is Brazil, without a definitive locality; the specimen examined for delineating $M$. s. eyerdami is referred to as coming from "Argentina, near Tartagal, Prov. Salta, close to the Bolivian border").

\subsection{Environmental data}

Environmental variables for current climatic conditions were obtained from WorldClim v.1.4 (http://www.worldclim.org), at a spatial resolution of 30 arc seconds $\left(\sim 1 \mathrm{~km}^{2}\right)$. Nineteen bioclimatic variables and a topographic variable (altitude) were used as predictors (Table 1). These data were derived from weather station data spanning 1950-2000 (Hijmans et al. 2005). To estimate the influence of climate change on the potential future distribution, the same bioclimatic predictors for the time intervals 2040-2069 and 2070-2099 (hereafter referred to as 2050 and 2080, respectively) were downloaded from the Climate Change, Agriculture, and Food Security website (CCAFS; http://www.ccafs-climate.org), at a resolution of 30 arc seconds. The Intergovernmental Panel on Climate Change (IPCC) has defined various political and economic scenarios that are regularly used to make predictions about climate change (IPCC 2007). In this study, the A2 and B1 scenarios were evaluated using the Hadley Centre Coupled Model, v.3 (HadCM3), which has been reported to provide good results for South America (Marengo 2006; Souza et al. 2011). We included only one global climate model by the arguments provided in Cordellier et al. (2012). The A2 scenario can be considered as pessimistic (it describes a very heterogeneous world with continuously increasing population, and regionally oriented economic growth), whereas B1 is more optimistic (it supposes a convergent world with the same global population, that peaks in mid-century and declines thereafter, with rapid changes in economic structures toward a service and information 
Table 1 Bioclimatic variables used in model development. Temperatures are expressed in ${ }^{\circ} \mathrm{C} * 10$, precipitations in $\mathrm{mm}$, and elevation in $\mathrm{m}$ above sea level

\begin{tabular}{ll}
\hline Variable & Description \\
\hline alt & Altitude \\
bio1 & Annual mean temperature \\
bio2 & Mean diurnal range (monthly mean, $\mathrm{T}^{\circ}$ max- $\mathrm{T}^{\circ}$ min) \\
bio3 & Isothermality (bio2/bio7) $\times 100$ \\
bio4 & Temperature seasonality (standard deviation $\times 100$ ) \\
bio5 & Maximum temperature of warmest month \\
bio6 & Minimum temperature of coldest month \\
bio7 & Temperature annual range (bio5-bio6) \\
bio8 & Mean temperature of wettest quarter \\
bio9 & Mean temperature of driest quarter \\
bio10 & Mean temperature of the warmest quarter \\
bio11 & Mean temperature of coldest quarter \\
bio12 & Annual precipitation \\
bio13 & Precipitation of wettest month \\
bio14 & Precipitation of driest month \\
bio15 & Precipitation seasonality (coefficient of variation) \\
bio16 & Precipitation of wettest quarter \\
bio17 & Precipitation of driest quarter \\
bio18 & Precipitation of the warmest quarter \\
bio19 & Precipitation of the coldest quarter \\
\hline
\end{tabular}

economy, with reductions in material intensity and the introduction of clean and resourceefficient technologies) (IPCC 2007; Xu et al. 2013). All environmental layers were clipped to the extent of the study area.

\subsection{Distribution modeling}

Low density populations and individuals buried in the soil, even after they die, confirm the inherent difficulties involved in validating absence for Megalobulimus (Hylton Scott 1939; Bequaert 1948). For this reason, the potential distribution of M. sanctipauli was estimated by using the MaxEnt algorithm (MaxEnt v.3.3.3 k; Phillips et al. 2006; Phillips and Dudík 2008). We chose MaxEnt as it requires presence-only data, and because several SDMs have been successfully generated by using this algorithm with very few presence records (e.g., Pearson et al. 2007; Kumar and Stohlgren 2009; Thorn et al. 2009). MaxEnt models the species' ecological niche (a set of ecological conditions habitable by a species) by examining the relationship between the locations of known species presence and the environmental characteristics of that area and then extrapolating from this the areas where similar conditions occur in the study area (Paredes-García et al. 2011; Vogler et al. 2013). $75 \%$ of presence records were randomly selected and used in the model training while the remaining $25 \%$ were used in the model testing. The potential distribution was computed as logistic under current climatic conditions first, and then projected onto future climate scenarios. This output returns a continuous map with an estimated probability of presence between 0 (no probability of the species presence) and 1 (high probability of presence), which permits fine distinctions between the suitability of different areas modeled (Giovanelli et al. 2008). All other parameters were 
used by default. The resulting model was evaluated using the Area Under the Curve (AUC) of the Receiver Operating Characteristic curve (ROC curves analyses; Fielding and Bell 1997). The AUC is a threshold independent index commonly used to assess prediction maps (Graham et al. 2011), which can take values between 0.5 (no predictability) and 1 (perfect prediction). According to Loo et al. (2007), values above 0.8 indicate a strong prediction. In order to compare and combine current and future potential distributions, binary maps (suitable/unsuitable habitat) were derived using the 10 percentile training presence logistic threshold, which considers the probability at which $10 \%$ of the most extreme training presence records are omitted (Morueta-Holme et al. 2010; Escalante et al. 2013). This strategy allowed us to identify those distribution areas strongly affected by climate change, as well those stable areas and new suitable areas for the species in the future. The extent of suitable areas (current and future) was quantified and analyzed with ArcGIS v.9.3 (ESRI 2008).

\subsection{Protected areas analysis}

In order to determine the potential extent of protected areas that are bioclimatically suitable for M. sanctipauli, the future distribution maps for the different scenarios and time slices were overlapped onto the current network of South American protected areas. The network was downloaded, considering all available categories, from the World Database of Protected Areas (UNEP-WCMC 2012; http://protectedplanet.net). Calculations were performed using ArcGIS v.9.3 (ESRI 2008).

\section{Results}

The potential distribution area for M. sanctipauli under current climatic conditions is shown in Fig. 2. The model had very good performance, with AUC values of 0.992 for training data and 0.966 for test data, with a standard deviation of 0.018 . The 10 percentile training presence
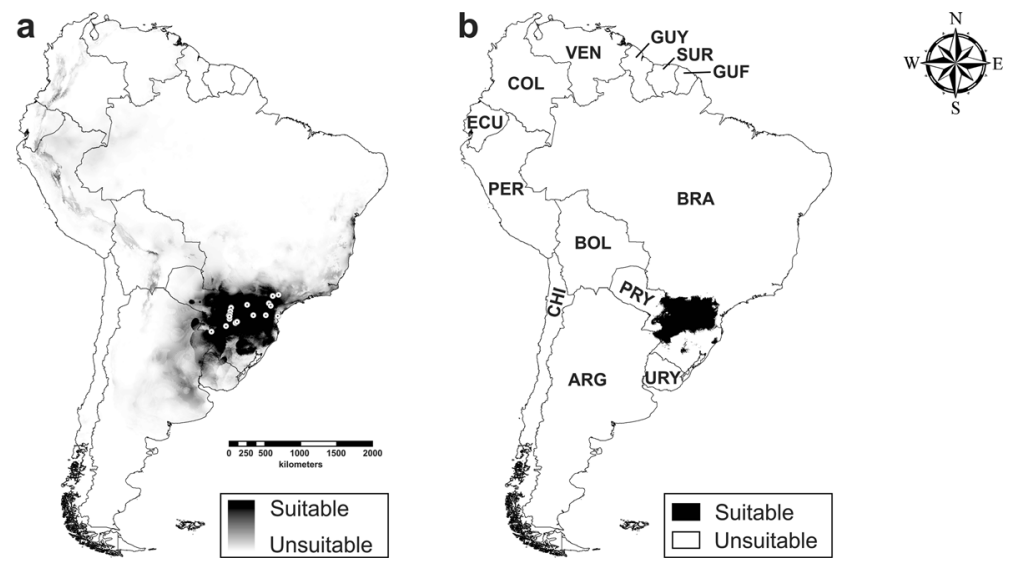

Fig. 2 Present potential distribution of Megalobulimus sanctipauli in South America. a logistic format, b thresholded format (10 percentile training presence). Darker areas indicate high suitability areas. Point indicate occurrence records used in study. ARG: Argentina; BOL: Bolivia; BRA: Brazil; CHI: Chile; COL: Colombia; ECU: Ecuador; GUF: French Guiana; GUY: Guyana; PRY: Paraguay; PER: Peru; SUR: Suriname; URY: Uruguay; VEN: Venezuela 
logistic threshold used for binomial conversion was 0.360. At this threshold, the area predicted as suitable for the species was about $2.17 \%$ of the extent of South America $\left(\sim 386,543 \mathrm{~km}^{2}\right.$; Fig. 3).

Under current conditions, the highest suitability values were found to be restricted to the Atlantic Rainforest, involving central-eastern Paraguay, north-eastern Argentina and southern Brazil (Fig. 2b). Projections of future distribution showed marked differences in habitat suitability among the different scenarios and times slices (Fig. 4). Under the low-emission B1 scenario, the suitable area for M. sanctipauli in South America was estimated to be about $2.59 \%\left(\sim 461,881 \mathrm{~km}^{2}\right)$ by 2050 , and $2.51 \%\left(\sim 447,049 \mathrm{~km}^{2}\right)$ by 2080 (Fig. 3). When compared with the currently suitable area, this was translated into a relative increase of $19.35 \%\left(\sim 75,338 \mathrm{~km}^{2}\right)$ and $15.67 \%\left(\sim 60,506 \mathrm{~km}^{2}\right)$ for 2050 and 2080 , respectively. In this predicted future distribution, the area gain was at expense of a northern retraction, but a southern expansion of the area indicated as suitable at present (Fig. 4a, b). The future projection with the high-emission A2 scenario was more extreme than the B1 scenario. Under the A2 scenario, the suitable area for the species in South America was estimated to be about $1.31 \%\left(\sim 233,622 \mathrm{~km}^{2}\right)$ by 2050, and $0.59 \%\left(\sim 104,525 \mathrm{~km}^{2}\right)$ by 2080 (Fig. 3); which represented a relative decrease in present potential range of $39.63 \%\left(\sim 152,921 \mathrm{~km}^{2}\right)$ and $72.81 \%\left(\sim 282,018 \mathrm{~km}^{2}\right)$ for 2050 and 2080 , respectively. Under this scenario, a retraction in the north and an expansion towards the south of the present potential distribution were predicted by 2050 (Fig. 4c). By 2080, most of the suitable area of the present potential distribution was projected to be lost, with an extreme northern retraction and the gain of a new disjunct area toward the south (Fig. 4d).

A total of 172 protected areas located in Argentina $(n=47)$, Brazil $(n=107)$, and Paraguay $(n=18)$ were found to contain climatically suitable habitat for the species at present and future; although the suitability differed among scenarios and periods analyzed (Electronic Supplementary Table). The amount of suitable habitat in protected areas under both scenarios for 2050 and 2080 is shown in Fig. 5. The simultaneous analysis under both scenarios and periods showed that from protected areas listed in the Electronic Supplementary Table, only four in Argentina and 20 in Brazil, accounting for $\sim 1545 \mathrm{~km}^{2}$ (0.009\% of South America), would remain suitable for the species by the end of the century (Table 2, Fig. 5).

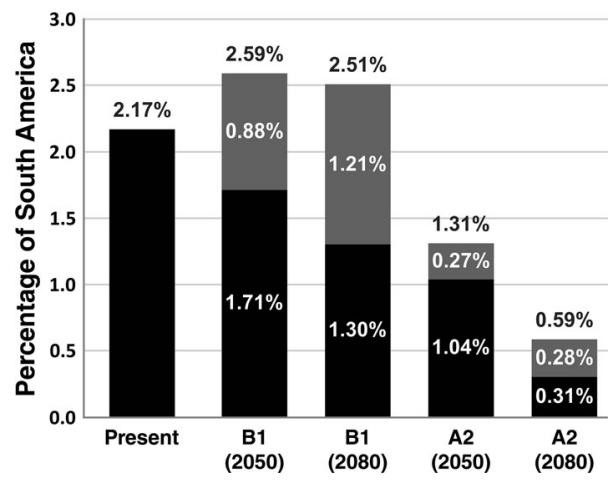

Fig. 3 Percentage of areas of South America suitable for Megalobulimus sanctipauli. Under future climate scenarios, black bars indicate areas suitable at present and future (stable), whereas grey bars indicate new suitable areas at future (expansion) 
a

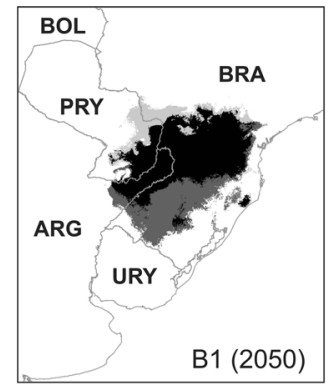

C

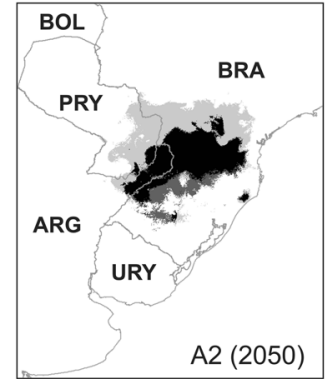

b

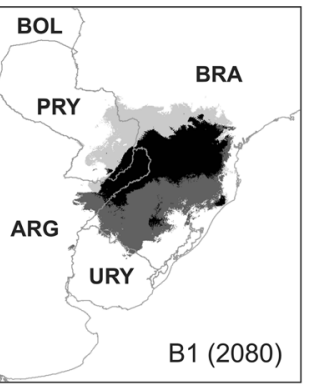

d

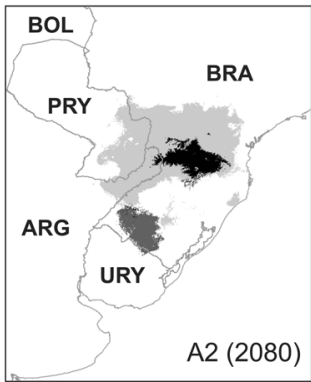

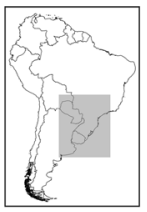

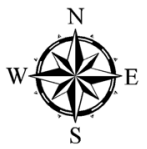

1000 kilometers

Retraction

(suitable at present)

Suitable

(present and future)

Expansion

(suitable at future)

Unsuitable

Fig. 4 Comparison among results of projections at present and future. Each map shows potential suitable areas for Megalobulimus sanctipauli under a future scenario for a time slice. a B1, 2050; b B1, 2080; c A2, 2050; and d A2, 2080. All maps are classified in: retraction (suitable areas at present but not at future), expansion (suitable areas at future but not at present), suitable areas at present and future, and unsuitable areas

\section{Discussion}

Land snails belong to the second most diverse animal phylum in terms of number of described species, and the estimated number of terrestrial gastropods comprises about 24,000 valid species (Lydeard et al. 2004). However, mollusks have the highest number of documented extinctions of any major taxonomic group (Lydeard et al. 2004). In particular, land snails are at disproportionately high extinction risk. Of the 310 mollusk species listed as extinct in the 2014 IUCN Red List of Threatened Species, 204 ( $66 \%$ ) are land gastropod species (IUCN 2014). Furthermore, the number of known extinctions is certainly underestimated (Régnier et al. 2009).

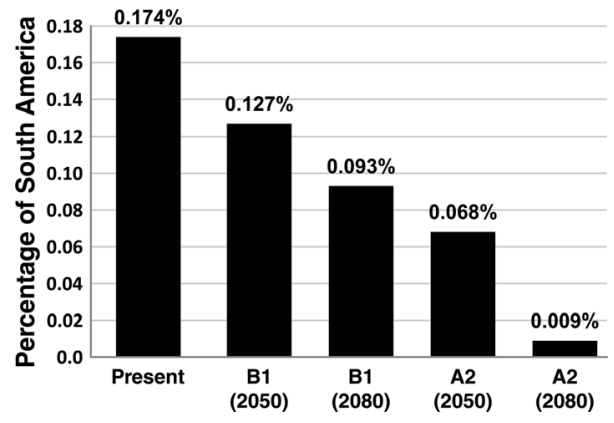

Fig. 5 Percentage of protected areas of South America suitable for Megalobulimus sanctipauli. Under future climate scenarios, only stable areas (suitable at present and future) are shown 
Table 2 Protected areas predicted to be suitable at present that will remain climatically suitable in the future for Megalobulimus sanctipauli under both scenarios and time slices examined

\begin{tabular}{|c|c|c|c|}
\hline Name & $\begin{array}{l}\text { IUCN management } \\
\text { category }\end{array}$ & Type of protected area & $\begin{array}{l}\text { Designation } \\
\text { type }\end{array}$ \\
\hline \multicolumn{4}{|l|}{ Argentina } \\
\hline Cruce Caballero & II & Provincial Park & National \\
\hline General Belgrano & VI & Forest Reserve & National \\
\hline Piñalito & II & Provincial Park & National \\
\hline San Antonio & Ia & Strict Nature Reserve & National \\
\hline \multicolumn{4}{|l|}{ Brazil } \\
\hline Araucárias & II & State Park & National \\
\hline Boa Vista - PR & Not Reported & Indigenous Area & National \\
\hline Buriti & IV & $\begin{array}{l}\text { State Area of Outstanding Ecological } \\
\text { Interest }\end{array}$ & National \\
\hline Caçador & VI & National Forest & National \\
\hline Campos de Palmas & III & Wildlife Refuge & National \\
\hline Mangueirinha & Not Reported & Indigenous Reserve & National \\
\hline Mata Preta & Ia & Ecological Station & National \\
\hline Palmas & II & State Park & National \\
\hline Palmas & Not Reported & Indigenous Area & National \\
\hline Palmital & Not Reported & Indigenous Area & National \\
\hline Pinhão & VI & State Forest Reserve & National \\
\hline Rio Areia & Not Reported & Indigenous Area & National \\
\hline Rio das Cobras & Not Reported & Indigenous Area & National \\
\hline Rio dos Pardos & Not Reported & Indigenous Area & National \\
\hline Rio dos Touros & Ia & State Ecological Station & National \\
\hline Santana & VI & State Forest & National \\
\hline Serra da Esperança & $\mathrm{V}$ & State Environmental Protection Area & National \\
\hline Toldo Imbu & Not Reported & Indigenous Area & National \\
\hline Três Barras & VI & National Forest & National \\
\hline Xapecó (Pinhalzinho-Canhadao) & Not Reported & Indigenous Area & National \\
\hline
\end{tabular}

In general terms, the conservation status of most land snails of the Neotropical Region remains unknown (Ramírez et al. 2003; Gutiérrez Gregoric et al. 2013). Despite this uncertainty, what is certain is that the group of giant land snails belonging to Megalobulimus is highly imperiled (Santos et al. 2013 and references therein). Six species are on the IUCN Red List: one extinct, two critically endangered, and three endangered (IUCN 2014). Furthermore, several species not listed that were formerly widespread are now fast declining in nature, as the result of anthropogenic pressures (Agudo-Padrón 2011). In this context, our study shows that climate change may pose an additional serious threat to giant land snails, where impacts on distributional ranges should be expected following the progressive warming predicted for the Neotropical region (IPCC 2007).

For the species studied here, our results suggest a future southern displacement of its distributional range in response to climate change, in agreement with the expected trend of distributional shifts to higher latitudes (Foden et al. 2008; Johnson et al. 2010). In spite of this, although the estimated change pattern in suitable areas for $M$. sanctipauli differed depending 
on the scenario and period examined, the north of the current potential distribution will likely have the most damaging consequences due to habitat loss by warming; thus, such loss could be expected to result in increased extinctions of local populations. In contrast, new contiguous and discontigous areas are predicted to increase suitability toward the south of the potential distribution, which might be colonized by the species. However, even though migration or dispersal rates are unknown for the species of Megalobulimus, colonization of new favorable areas seems fairly improbable as it necessarily would require high dispersal abilities. This is in contrast with low dispersal of most land snails where the overall general rate of active migration has been estimated to be in the order of $2.60 \mathrm{~m}$ per month (Barker 2001; Foden et al. 2008; Kramarenko 2014; Miranda et al. 2015). On this basis, it can be expected that future distribution of $M$. sanctipauli will probably be restricted only to those stable areas indicated as suitable at present and future, which in the less optimistic scenario would represent $0.31 \%$ of continental South America by 2080 (Fig. 3).

In addition to above mentioned impacts, it is important to note that the predicted potential distribution for $M$. sanctipauli refines the previous understanding about the distribution of this species, which was indicated to occur in southern Brazil, eastern Paraguay and northeastern Argentina (Parodiz 1957; Fernández 1973; Simone 2006; Beltramino et al. 2012; Beltramino 2013). Our results draw attention to the idea that this giant land snail seems to be restricted exclusively to the southernmost regions of the Atlantic Forest, and mainly to the ecoregions of the Araucaria and the Upper Paraná Atlantic Forests (Di Bitetti et al. 2003; Paviolo et al. 2008). This refined distribution analysis becomes particularly important when taking into account that the Atlantic Forest, one of the world's biodiversity hotpots, faces an increasing number of threats (Di Bitetti et al. 2003). This was one of the largest forests of the Americas, extending into tropical and subtropical regions (Ribeiro et al. 2009). However, it is currently one of the most threatened forests, in which less than $7 \%$ of the original vegetation cover remains, essentially as the result of deforestation especially associated with the expansion of agriculture and other land uses (Di Bitetti et al. 2003; Paviolo et al. 2008; Ribeiro et al. 2009). In this context, the synergistic impact of the ongoing habitat destruction with climate change is likely to result in a serious decrease of the suitable habitat for the giant land snail studied here, as well for most of the malacofauna sharing the same habitat.

Beyond these considerations, southernmost ecoregions of the Atlantic Forest still contain some of the largest intact fragments of forest, especially in Argentina and Paraguay, many of which are represented in existing protected areas (Di Bitetti et al. 2003; Paviolo et al. 2008). In order to mitigate impacts, those protected areas indicated in our results as suitable at present that will remain climatically suitable in the future (Table 2) should deserve particular attention for setting conservation priorities. In this sense, the highlighted protected areas need to be surveyed first to confirm the real occurrence of $M$. sanctipauli, as they may actually be devoid of populations due to several interlinked factors not considered in this study which could influence the species' distribution (e.g., barriers, invasive species, interactions, predators, smaller-scale habitat properties; Barker 2001).

In addition, and in the same way as for other species, it is important to bear in mind that our prognosis is not free of methodological uncertainty due to data sources and modeling method used, and results could be different using other climate and niche models; although we consider that future trends will be similar in light of the currently available resources. Nonetheless, this study has established a baseline for assessing the impacts of climate change in native giant land snails. We consider that application of bioclimatic models for the prognosis of future events of non-model organisms as those belonging to the giant land snail fauna, in 
which also umbrella and flagship species are being proposed, is a promising initiative to address conservation efforts that may enable governmental authorities to develop climateintegrated conservation plans aimed to preserve threatened malacofauna diversity.

Acknowledgments We thank the Agencia Nacional de Promoción Científica y Tecnológica (BID-PICT-20082042) for funding this study. We are especially grateful to Dr. Bram Breure (Naturalis Biodiversity Center, The Netherlands) for providing valuable comments on an early version of the manuscript.

\section{References}

Agudo-Padrón AI (2011) Threatened freshwater and terrestrial molluscs (Mollusca, Gastropoda: Bivalvia) of Santa Catarina State, Southern Brazil: check list and evaluation of regional threats. Biodivers J 2(2):59-66 Barker GM (2001) The biology of terrestrial molluscs. CABI, Wallingford

Bellard C, Bertelsmeier C, Leadley P, Thuiller W, Courchamp F (2012) Impacts of climate change on the future of biodiversity. Ecol Lett 15:365-377

Beltramino AA (2013) Distribution of Megalobulimus sanctipauli (Ihering and Pilsbry, 1900) (Gastropoda: Megalobulimidae) in South America. Check List 9(2):469-471

Beltramino AA, Vogler RE, Rumi A (2012) Megalobulimus sanctipauli (Ihering y Pilsbry, 1900): antecedentes de la especie. Amici Molluscarum 20(2):19-24

Bequaert JC (1948) Monograph of the Strophocheilidae, a neotropical family of terrestrial mollusks. Bull Mus Comp Zool 100(1):1-210

Bonard AR, Caldini CH, Miquel SE (2012) Mirinaba fusoides (Bequaert, 1948) (Mollusca, Strophocheilidae): primer registro de la especie en la República Argentina. Hist Nat (B Aires) 2(2):95-100

Breure ASH, Romero PE (2012) Support and surprises: molecular phylogeny of the land snail superfamily Orthalicoidea using a three-locus gene analysis with a divergence time analysis and ancestral area reconstruction. Arch Molluskenkunde 141:1-20

Cordellier M, Pfenninger A, Streit B, Pfenninger M (2012) Assessing the effects of climate change on the distribution of pulmonate freshwater snail biodiversity. Mar Biol 159:2519-2531

Di Bitetti MS, Placci G, Dietz LA (2003) Visión de biodiversidad de la ecorregión del Bosque Atlántico del Alto Paraná. World Wildlife Fund, Washington D.C

Eggers S, Parks M, Grupe G, Reinhard KJ (2011) Paleoamerican diet, migration and morphology in Brazil: archaeological complexity of the earliest Americans. PLoS ONE 6(9), e23962. doi:10.1371/journal.pone. 0023962

Escalante T, Rodríguez-Tapia G, Linaje M, Illoldi-Rangel P, González-López R (2013) Identification of areas of endemism from species distribution models: threshold selection and Nearctic mammals. TIP Rev Esp Cienc Quím Biol 16:5-17

ESRI (2008) ArcGIS v.9.3. ESRI, Redlands, California, USA

Fernández D (1973) Catálogo de la malacofauna terrestre argentina. Comisión de Investigaciones Científicas de la Provincia de Buenos. Aires, La Plata

Fernández D (1978) Nota sobre Strophocheilus sinistrales (Moll. Gastr.). Neotropica 24(72):149-150

Fielding AH, Bell JF (1997) A review of methods for the assessment of prediction errors in conservation presence/absence models. Environ Conserv 24:38-49

Fischer ML, Costa LCM (2010) O caramujo Gigante Africano Achatina fulica no Brasil. Champagnat, Curitiba

Foden W, Mace G, Vié JC, Angulo A, Butchart S, DeVantier L, Dublin H, Gutsche A, Stuart S, Turak E (2008) Species susceptibility to climate change impacts. In: Vié JC, Hilton-Taylor C, Stuart SN (eds) The 2008 review of the IUCN red list of threatened species. IUCN Gland, Switzerland, pp 1-11

Franklin J, Davis FW, Ikegami M, Syphard AD, Flint LE, Flint AL, Hannah L (2013) Modeling plant species distributions under future climates: how fine scale do climate projections need to be? Glob Chang Biol 19(2): $473-483$

Giovanelli JGR, Haddad CFB, Alexandrino J (2008) Predicting the potential distribution of the alien invasive American bullfrog (Lithobates catesbeianus) in Brazil. Biol Invasions 10:585-590

Graham CH, Loiselle BA, Velásquez-Tibatá J, Cuesta F (2011) Species distribution modeling and the challenge of predicting future distributions. In: Herzog SK, Martinez R, Jørgensen PM, Tiessen H (eds) Climate change and biodiversity in the Tropical Andes. Inter-American Institute for Global Change Research (IAI) and Scientific Committee on Problems of the Environment (SCOPE), São José dos Campos and Paris, pp 295-310

Gutiérrez Gregoric DE, Núñez V, Vogler RE, Beltramino AA, Rumi A (2013) Gasterópodos terrestres de la provincia de Misiones, Argentina. Rev Biol Trop 61:1759-1768 
Hijmans RJ, Cameron SE, Parra JL, Jones PG, Jarvis A (2005) Very high resolution interpolated climate surfaces for global land areas. Int J Climatol 25:1965-1978

Hylton Scott MI (1939) Estudio anatómico del Borus "Strophocheilus lorentzianus" (Doer.) (Mol. Pulm.). Revista Mus La Plata 1(Zool): 217-278

IPCC (2007) Climate change 2007: the physical science basis. Contribution of working group I to the fourth assessment report of the Intergovernmental Panel on Climate Change. Cambridge University Press, Cambridge

IUCN (2014) IUCN Red List of Threatened Species. Version 2014.3. http://www.iucnredlist.org. Accessed 18 Dec 2014

Jaramillo Roldán E, López Martínez J, Ramírez R, Velásquez Trujillo LE (2014) Análisis morfológico del sistema reproductor e identificación molecular a través de los marcadores mitocondriales COI y 16S rRNA de Megalobulimus oblongus (Mollusca, Strophocheilidae) de Colombia. Rev Per Biol 21:79-88

Jeschke JM, Strayer DL (2008) Usefulness of bioclimatic models for studying climate change and invasive species. Ann N Y Acad Sci 1134:1-24

Johnson DM, Büntgen U, Frank DC, Kausrud K, Haynes KJ, Liebhold AM, Esper J, Stenseth NC (2010) Climatic warming disrupts recurrent Alpine insect outbreaks. Proc Natl Acad Sci U S A 107:20576-20581

Kramarenko CC (2014) Active and passive dispersal of terrestrial mollusks: a review. Ruthenica 24(1):1-14

Kumar S, Stohlgren TJ (2009) Maxent modeling for predicting suitable habitat for threatened and endangered tree Canacomyrica monticola in New Caledonia. J Ecol Nat Environ 1(4):94-98

Loo SE, Mac Nally R, Lake PS (2007) Forecasting New Zealand mudsnail invasion range: model comparisons using native and invaded ranges. Ecol Appl 17:181-189

Lydeard C, Cowie RH, Ponder WF, Bogan AE, Bouchet P, Clark SA, Cummings KS, Frest TJ, Gargominy O, Herbert DG, Hershler R, Perez KE, Roth B, Seddon M, Strong EE, Thompson FG (2004) The global decline of nonmarine mollusks. Bioscience 54:321-330

Marengo JA (2006) Mudanças climáticas globais e seus efeitos sobre a biodiversidade: caracterização do clima atual e definição das alterações climáticas para o território brasileiro ao longo do século XXI, 2nd edn. Ministério do Meio Ambiente, Brasília

Miranda MS, Fontenelle JH, Pecora IL (2015) Population structure of a native and an alien species of snail in an urban area of the Atlantic Rainforest. J Nat Hist 49:19-35

Morueta-Holme N, Fløjgaard C, Svenning JC (2010) Climate change risks and conservation implications for a threatened small-range mammal species. PLoS ONE 5(4), e10360. doi:10.1371/journal.pone.0010360

Paredes-García DM, Ramírez-Bautista A, Martínez-Morales MA (2011) Distribución y representatividad de las especies del género Crotalus en las áreas naturales protegidas de México. Rev Mex Biodivers 82:689-700

Parodiz JJ (1957) Catalogue of the land Mollusca of Argentina. Nautilus 70:127-135

Paviolo A, De Angelo CD, Di Blanco YE, Di Bitetti MS (2008) Jaguar Panthera onca population decline in the Upper Paraná Atlantic Forest of Argentina and Brazil. Oryx 42:554-561

Pearson RG, Raxworthy CJ, Nakamura M, Peterson AT (2007) Predicting species distributions from small numbers of occurrence records: a test case using cryptic geckos in Madagascar. J Biogeogr 34:102-117

Phillips SJ, Dudík M (2008) Modeling of species distributions with Maxent: new extensions and a comprehensive evaluation. Ecography 31:161-175

Phillips SJ, Anderson RP, Schapire RE (2006) Maximum entropy modeling of species geographic distributions. Ecol Model 190:231-259

Quintana MG (1982) Catálogo preliminar de la malacofauna del Paraguay. Rev Mus Argent Cienc Nat 11(3):61158

Ramírez R, Paredes C, Arenas J (2003) Moluscos del Perú. Rev Biol Trop 51(Suppl 3):225-284

Régnier C, Fontaine B, Bouchet P (2009) Not knowing, not recording, not listing: numerous unnoticed mollusk extinctions. Conserv Biol 23:1214-1221

Ribeiro MC, Metzger JP, Martensen AC, Ponzoni FJ, Hirota MM (2009) The Brazilian Atlantic forest: how much is left and how is the remaining forest distributed? Implications for conservation. Biol Constr 142: 1141-1153

Salgado NC, Coelho ACS (2003) Moluscos terrestres do Brasil (Gastrópodes operculados ou não, exclusive Veronicellidae, Milacidae e Limacidae). Rev Biol Trop 51(Suppl 3):149-189

Santos SB (2011) Land snails as flagship and umbrella species for Brasilian Atlantic Forest conservation. Tentacle 19:19-20

Santos SB, Miyahira IC, Mansur MCD (2013) Freshwater and terrestrial molluscs in Brasil: current status of knowledge and conservation. Tentacle 21:40-42

Sen S, Ravikanth G, Aravind NA (2012) Land snails (Mollusca: Gastropoda) of India: status, threats and conservation strategies. J Threat Taxa 4(11):3029-3037

Simone LRL (2006) Land and freshwater molluscs of Brazil. Editorial EGB-Fapesp, São Paulo 
Souza TVD, Lorini ML, Alves MAS, Cordeiro P, Vale MM (2011) Redistribution of threatened and endemic Atlantic Forest birds under climate change. Nat Conserv 9(2):214-218

Thomas CD, Cameron A, Green RE, Bakkenes M, Beaumont LJ, Collingham YC, Erasmus BFN, Ferreira de Siqueira M, Grainger A, Hannah L, Hughes L, Huntley B, van Jaarsveld AS, Midgley GF, Miles L, OrtegaHuerta MA, Townsend Peterson A, Phillips OL, Williams SE (2004) Extinction risk from climate change. Nature 427:145-148

Thorn JS, Nijman V, Smith D, Nekaris KAI (2009) Ecological niche modelling as a technique for assessing threats and setting conservation priorities for Asian slow lorises (Primates: Nycticebus). Divers Distrib 15: 289-298

UNEP-WCMC (2012) Data standards for the world database on protected areas. UNEP-WCMC, Cambridge

Vale MM, Alves MAS, Lorini ML (2009) Mudanças climáticas: desafios e oportunidades para a conservação da biodiversidade brasileira. Oecol Bras 13:518-535

Vogler RE, Beltramino AA, Sede MM, Gutiérrez Gregoric DE, Núñez V, Rumi A (2013) The giant African snail, Achatina fulica (Gastropoda: Achatinidae): using bioclimatic models to identify South American areas susceptible to invasion. Am Malac Bull 31:39-50

Wieczorek J, Guo Q, Hijmans RJ (2004) The point-radius method for georeferencing locality descriptions and calculating associated uncertainty. Int J Geogr Inf Sci 18(8):745-767

Xu Z, Feng Z, Yang J, Zheng J, Zhang F (2013) Nowhere to invade: Rumex crispus and Typha latifolia projected to disappear under future climate scenarios. PLoS ONE 8(7), e70728. doi:10.1371/journal.pone.0070728 